\title{
Slocum, Rachel \& Arun Saldanha (eds), Geographies of Race and Food: Fields, Bodies, Markets, Farnham: Ashgate, 2013.
}

\author{
Recensão de Joana Caetano \\ CETAPS/ Universidade do Porto
}

Geographies of Race and Food: Fields, Bodies, Markets, volume organizado por Rachel Slocum, da Universidade de Wisconsin, e Arun Saldanha, do Lancaster Environment Centre, é um estudo multidisciplinar, multinacional e multicultural que, ao contrário da prática ainda comum, analisa casos de estudo localizados fora do contexto europeu e norteamericano, alargando o espaço de investigação a países das Américas Central e do Sul, da Oceânia e de África. Apesar do crescente interesse da Academia nos Estudos sobre a Alimentação e das múltiplas e diversificadas abordagens publicadas sobre esta temática nos últimos anos, temos de reconhecer que esta é ainda uma área pouco investigada fora do campo da nutrição. Uma das lacunas reconhecidas, e que esta coletânea de ensaios tenta colmatar, é a questão da raça e das suas várias implicações na alimentação. Apesar de a raça ser um tópico de análise recorrente nas Humanidades e nas Ciências Sociais, esta parece ser a mais recente das raras publicações que se debruçam sobre a complexa relação entre raça e alimentação, partindo de uma perspetiva espacial, geográfica e do corpo.

Como expõe Julie Guthman na nota prévia, investigadores de várias disciplinas combinam aqui os seus conhecimentos e interesse na alimentação com literaturas mais 
antigas e desenvolvidas sobre formação racial e étnica, pós-colonialismo e movimentos sociais que lutam contra o racismo institucionalizado dentro e fora dos EUA. Neste sentido, a motivação principal da organização deste volume é a necessidade reconhecida de se descentralizar a discussão sobre a alimentação do designado “Ocidente”, denunciar os preconceitos criados pela visão hegemónica da cultura branca [whiteness] e desconstruir estereótipos raciais, como por exemplo a exotização ou a vilanização das raças não-brancas.

Para cumprir este objetivo, os autores propõem-se, em primeiro lugar, construir uma teorização mais aprofundada da questão da raça que enfatiza a sua corporalidade e a sua materialidade e, em segundo, expandir os ambientes e contextos em que raça e alimentação se interligam para incluírem a análise de dinâmicas como o pós-colonialismo e as mudanças climáticas.

O capítulo introdutório assinado pelos organizadores, bem como o capítulo "Race in the Study of Food" por Slocum são de destacar, pois apresentam e desenvolvem uma moldura teórica inovadora. Slocum e Saldanha abrem o volume com uma definição do conceito de raça e a clarificação das principais características diferenciadoras desse conceito. Segundo os autores,

- A racialização tem duas componentes: a cultura e a biologia. Contudo, em questões de raça, a ênfase deve ser dada ao fenótipo, ou seja, às características morfológicas, fisiológicas e comportamentais do indivíduo e não à sua construção social e performativa.

- Tendo em conta o fenótipo, não há raças, apenas características distintas em todos os seres humanos. A raça é um processo de tentativa de estabilização das diferenças populacionais fomentado pelo capitalismo colonial.

- O ambiente está diretamente racializado, isto é, há desigualdades na produção, no acesso e no consumo alimentares: como por exemplo, a fome numa parte do globo, e na outra parte, o desperdício alimentar.

- Se a raça é segregação e categorização, a colonização europeia e o capital industrial foram e continuam a ser as suas forças motrizes. 
- O nacionalismo biopolítico europeu e a colonização definiram a raça branca [whiteness] como a norma contra a qual todas as outras raças são (pejorativamente) avaliadas.

Na teorização da raça, conceitos como "representatividade" e "materialidade" são incontornáveis. Partindo de correntes neomaterialistas e/ou socio-construtivistas, e aliando-as às teorias de Judith Butler, Jacques Derrida e Michel Foucault, Slocum analisa o corpus científico disponível dentro e fora das geografias, procurando dar respostas a questões como:

1. O que é a raça em termos éticos, biológicos, sociais e espaciais?

2. Em que se transforma a alimentação quando ponderamos a raça?

3. Poderemos ver a raça de forma distinta quando são analisadas as práticas alimentares?

4. Que implicações tem a raça na produção, na comercialização e no consumo de alimentos?

Sendo os corpos moldados em termos raciais pelo trabalho, pelo que comem e onde vivem, a raça é um processo físico contínuo de interação entre seres vivos. Deve ser, por isso, compreendida como uma interação entre os corpos e as substâncias que ingerem, as posses que acumulam e as ferramentas que utilizam (Weismantel apud Slocum \& Saldanha, 43). Só desta forma se poderá compreender como a raça é formada e como ela constitui a sociedade.

Depois desta complexa exposição teórica nos primeiros dois capítulos, os restantes textos encontram-se agrupados em três grandes categorias temáticas: Parte I. Fields Ecology, Labor, Inequality; Parte II. Bodies - Diet, Taste, Biopolitics; Parte III. Markets Exchange, Commodification, Empire. Analisando casos de estudo desde a escravatura de populações africanas nas Caraíbas a programas a decorrer na Califórnia, passando pelo nordeste brasileiro e a África do Sul, os capítulos da primeira secção concentram-se na organização de regimes de trabalho e/ou exploração laboral que são claramente 
racializados. Por outro lado, os casos presentes na secção dedicada à corporalidade denunciam como todos os corpos são racializados, pois a expansão do capitalismo, através da exploração mineira, do transporte de bens e mercadorias, e ainda o turismo e o aquecimento global, entre outros fatores, aprisionam todos os corpos numa máquina gigante que lhes atribui nutrientes, fármacos, venenos, hábitos alimentares e sensações em níveis muito díspares, baseando-se na raça (9). A terceira secção debruça-se sobre a complexidade das trocas comerciais. Os mercados são o meio que liga os campos de produção e as populações através da circulação de produto e capital. Ao longo da História, o comércio ligou tribos e sociedades; contudo, o sistema mercantilista construiu-se essencialmente sobre a exploração do trabalho de muitos e a prosperidade de poucos. Alguns desses casos são abordados nesta terceira última parte.

Ao longo do volume, percebemos que a relação entre raça e alimentação é complexa e multimodal, servindo a última ora de força motivadora de resistência face à opressão e/ou apropriação, cristalizando e protegendo identidades, ora de meio facilitador do cruzamento entre culturas. Sendo a alimentação um processo biológico marcado pela raça, cultura e poder, tanto poderá erguer muros como derrubá-los. Como David Sutton explica, a alimentação não simboliza meramente laços ou divisões sociais; ela participa na sua criação e re-criação (apud Slocum \& Saldanha, 39).

Somente após a identificação e o diagnóstico destas problemáticas raciais é que se poderá construir e desenvolver uma biopolítica ecológica de mérito. Como Slocum e Saldanha explanam, a ecologia humana é incompreensível fora do contexto do capitalismo, do Estado, da classe e casta, do género e da raça. Por essa razão torna-se urgente desenvolver uma ecologia política sensível à forma como a injustiça ambiental é constituída globalmente através de diferenças físicas e morfológicas [bodily differences] (7): só assim se poderá combater a iniquidade e construir uma sociedade mais justa e inclusiva.

Avançando um conjunto de argumentos bem fundamentados, Geographies of Race na Food propõe-se desconstruir e descentralizar a discussão da alimentação como uma mera questão nutricional e dietética, analisando-a a partir de um ponto de vista holístico como força motriz de mudança, com um claro pendor utópico. Como clarifica Slocum, toda a 
investigação presente na obra é crítica e anti-racista. A maioria dos autores enuncia manifestações de racismo e denuncia-as. Como defende a autora, teorizar a raça poderá conduzir a um entendimento de como a diferença é capaz de aproximar pessoas, lugares e ideias, possibilitando deste modo a construção de mundos futuros, mais igualitários, sustentáveis e justos. Através da análise da raça experimenta-se e projeta-se conceptualmente a vida e a mudança (26). 